\title{
Government Governance, Fiscal Transparency, and Government Accounting Information Sharing: Realization Mechanism and Path
}

\author{
Jilin $Q u^{1, a}$, Yicai Zhu ${ }^{1, b,{ }^{*}}$ \\ ${ }^{1}$ Shandong University of Finance and Economics Jinan, Shandong, China \\ aqujilin@126.com, bxpmwzyc@163.com \\ *Yicai Zhu
}

\begin{abstract}
Keywords: Government governance, Fiscal transparency, Government accounting information, Public disclosure, Sharing mechanism.
\end{abstract}

\begin{abstract}
Fiscal transparency is an important prerequisite for improving government governance, and the sharing of government accounting information is the basic guarantee for fiscal transparency. Aiming at the problems existing in the public disclosure of government accounting information in China, this paper puts forward the sharing mechanism and path of government accounting information under the network environment. We should establish an accounting information platform, and build a government accounting information sharing service system of vertical transfer, horizontal sharing, business integration, and openness and transparency, so as to realize the "single out and share resources" of government accounting information. Therefore, information users such as the public can easily obtain accounting information, and the government departments can realize the integration of accounting information and related businesses. It's helpful to improve fiscal transparency, and give full play to the role of government accounting in government governance.
\end{abstract}

\section{Introduction}

Fiscal transparency is an important prerequisite for the government's good governance, macroeconomic stability and fiscal fairness. It is also an inevitable requirement for establishing a sunshine government, a responsible government, and a service government ${ }^{[1]}$. At present, China's fiscal transparency still lags far behind other countries. Taking the "Open Budget Survey 2017" published by the International Budget Cooperation Organization (IBP) in 2017 as an example, China's fiscal transparency ranks 89 th among 102 countries $^{[2]}$.

This study is supported by the National Social Science Fund Project "Research on Accounting Information Sharing Mechanism from the Perspective of National Governance", No: 15BGL057.

The improvement of fiscal transparency is inseparable from the support of the government accounting system ${ }^{[3]}$. Public disclosure of government accounting information is the main means and basic guarantee for improving fiscal transparency. With regard to the problems existing in China's current government accounting information disclosure, scholars have conducted extensive research. However, there is no in-depth study on how information users can easily access and use government accounting information. Based on the analysis of the relationship between government governance, fiscal transparency and government accounting information sharing, this paper proposes the mechanism and path of realizing government accounting information sharing. The main contributions are as follows. First, analyze the role of government accounting information on fiscal transparency and government governance from the perspective of information sharing. Second, put forward the realization mechanism and path of government accounting information sharing. By establishing an accounting information platform, construct a vertical transfer, horizontal sharing, business integration, open and transparent government accounting information sharing service system, and realize the government accounting information "single out and share resources". 


\section{Government governance and fiscal transparency}

Fiscal transparency is an inevitable requirement for improving government governance. Government governance refers to the governance of public affairs by government administrative agencies ${ }^{[4]}$. Modern government governance theory holds that citizens and the government are principal-agent relationships. Citizens entrust public resources and power to government to manage ${ }^{[5]}$. The government should disclose the government structure and functions, fiscal policy tendencies, public sector accounts and fiscal planning to the public in detail, so that the public can supervise and evaluate government activities. Among them, fiscal transparency can best reflect government.

\subsection{Enhance the credibility of the government and build a service-oriented government that the people are satisfied with}

Fiscal transparency is an important guarantee for citizens' right to know and supervise. It is an effective way to realize the "enhancing the government's credibility and execution and building a satisfactory service-oriented government" proposed by China. First, improving fiscal transparency can help the public better understand the activities and behaviors of the government, let the people supervise power, let power run in the sun, enhance the credibility of the government, and build a service-oriented government that the people are satisfied with. Second, improving fiscal transparency effectively alleviate the information asymmetry between the public and the government, help the public to understand the intentions of government policies and actions, enhance public understanding and trust of the government, fully reflect the people's initiative to take ownership of their own affairs, and maintain social stability. Third, improving fiscal transparency contributes to the formulation of macroeconomic policies ${ }^{[6]}$.

\subsection{Scientifically evaluate government performance and improve government governance efficiency}

Government performance evaluation is the analysis, evaluation and measurement of the influence and effect of government decision-making and behavior in all aspects of society. It is an effective method and tool to regulate government administrative behavior and improve government governance efficiency. First, government financial information is the main source of information for government performance evaluation. Government performance evaluation is based on comprehensive, detailed and accurate government activity information. Government accounting and its generated financial reports can reflect the government activities in detail. It's an important basis for government performance evaluation. Improving fiscal transparency can ensure the scientific and effective evaluation of government performance. Second, improving fiscal transparency can significantly improve government performance. Fiscal transparency can promote government agencies to establish effective incentive and restraint mechanisms, regulate government behavior, and significantly improve government performance.

\subsection{Strengthen power supervision and prevent and control corruption}

Fiscal transparency can reflect government activities comprehensively, truthfully and objectively, and form effective supervision and restraint on the powers and behaviors of government departments and their public servants. First, improving fiscal transparency is beneficial to government departments to strengthen internal control. Improving fiscal transparency and strengthening internal control can effectively alleviate information asymmetry between functions and positions, break the "black box" of power manipulation, realize mutual supervision and checks and balances of various powers, and effectively curb rent-seeking behavior in government activities. Second, increasing fiscal transparency helps the public to strengthen external supervision. Improving fiscal transparency can fully reflect the activities and behaviors of the government, help the public to understand the content, process and effects of government activities, supervise and constrain the government's power operation, and effectively prevent and control corruption. 


\subsection{Prevent fiscal risks and improve fiscal efficiency}

Improving fiscal transparency, preventing fiscal risks and improving fiscal efficiency are mainly embodied in the following three aspects. First, control the fiscal scale to prevent the negative impact of excessive scale. Improve fiscal transparency, and the public can monitor the fiscal scale according to the government's budget report at the beginning of the year, executive report, and etc. Second, improve fiscal efficiency and promote the construction of a public fiscal system. Improving fiscal transparency is conducive to the effective supervision of government activities by the public, improving the formulation efficiency of public goods supply policies and the utilization efficiency of public fund management, and promoting the construction of the public fiscal system and the market economic system. Third, prevent fiscal risks and control the size and cost of government debt. Emergence of the expansion of government debt and the fiscal deficits are intuitively due to the government's inability to pay, but the key issue is the lack of fiscal transparency ${ }^{[5]}$. Improving fiscal transparency is conducive to the public's supervision and restraint on fiscal activities and behaviors, controlling the scale and cost of government debt, and improving fiscal security.

\section{Fiscal transparency and government accounting information sharing}

Government accounting information sharing is the basic guarantee of fiscal transparency. Accounting transparency is at the core of fiscal transparency ${ }^{[7]}$.

\subsection{Government accounting is an important basis for achieving fiscal transparency}

The improvement of fiscal transparency is inseparable from the support of the government accounting system ${ }^{[3]}$. Government accounting is an important basis for achieving fiscal transparency, and an effective tool for achieving good governance of the government. First, government accounting can fully reflect the government's fiscal revenue and expenditure, and is conducive to the establishment of a comprehensive, standardized, open and transparent budget system. Government accounting is the basis of budget management. It can comprehensively and clearly reflect the government budget execution information and financial activity information, and completely record and reflect the entire process and operation results of government budget revenues and expenditures at all levels, and play an important role in establishing a comprehensive, standardized and transparent budget system. Second, government accounting can faithfully reflect the government's "home" and help prevent fiscal risks. By recording government assets, liabilities, and etc, government accounting comprehensively and completely reflects the government's financial status and asset value preservation and appreciation. It is conducive to supervising and restricting government fiscal activities and behaviors, controlling government debt scale and costs, and preventing fiscal risks. Third, government accounting can truly reflect the government's operating costs, and is conducive to scientific evaluation of government performance. Government accounting implements the accrual system of the government's comprehensive financial reporting system, can comprehensively, detailedly and accurately reflect the government's cost and benefit information, and is convenient for rational evaluation of public resources benefit of government departments at all levels and various projects. It's conducive to more scientifically evaluate government performance and fulfillment of fiduciary duties.

\subsection{The main problems in the accounting information sharing of Chinese government}

Government accounting information sharing is an important basis for improving fiscal transparency and an effective tool for achieving good government governance. The development of network technology provides technical guarantee for government accounting information sharing. The public disclosure of government financial reports to the public through the network becomes a reality. However, there are still many problems in terms of content, manner and quality of public disclosure. First, the information acquisition channel is not smooth. At present, government accounting information is mainly disclosed by various departments and units, and the content and format are different. Information users such as the public, who need to know the information of various 
government departments, can only find it on the websites of various departments. Information acquisition and reading are very inconvenient, and the cost of acquisition is relatively high. Second, the quality of information disclosure is not high. At present, the disclosure of government accounting information is too simple and general, information readability and comprehensibility are poor, and there are phenomena such as formality ${ }^{[8]}$. Third, there is a lack of information sharing. Different government departments have different responsibilities, and the requirements for accounting information are different. Due to the lack of information sharing between departments, it's difficult to realize the organic integration of government accounting information and fiscal related business, and to ensure the scientific and effective macroeconomic management and decision-making of the government.

The problems above directly affect the role of government accounting information, and it is difficult to achieve the goal of improving fiscal transparency. The main reason is the decentralized management of government accounting information disclosure, their own governance, and the lack of uniform information disclosure norms and standards. In order to solve these problems, the government accounting information platform should be established in the fiscal department at or above the county level, responsible for the collection and public disclosure of government accounting information, to achieve comprehensive collection, centralized processing, and unified services.

\section{Realization mechanism and path of government accounting information sharing under the network environment}

Government accounting information sharing is based on the accounting information of government departments at all levels and units, through unified collection, review, summary and analysis, so that information users such as the public can easily obtain accounting information, government departments can achieve the integration of accounting information and related businesses, and "single out and share resources" of government accounting information can come true.

\subsection{Realization mechanism of government accounting information sharing}

According to the "Government Accounting Standards - Basic Principles", government accounting entities are state organs, military, political party organizations, social organizations, institutions, and other units that have direct or indirect budgetary appropriations with the fiscal departments of the government at the same level. Government accounting information users mainly include people's congresses at all levels and their standing committees, governments at all levels and their relevant departments, government accounting entities themselves, creditors, the public and other stakeholders. According to the demand characteristics of government accounting information users, accounting information users are divided into fiscal departments, government agencies, legislative bodies, the public and other stakeholders.

Government accounting information runs through all levels of government governance and is integrated into the main business of fiscal management. In order to realize the sharing of government accounting information and improve fiscal transparency, an accounting information platform shall be established in the fiscal department at or above the county level to be responsible for the collection, review and storage of government accounting information of various departments and units within the region. Through summary, analysis and etc, the government accounting information has been submitted to the higher fiscal departments step by step. Establish a government accounting information sharing service system that is vertically transferred, horizontally shared, business-integrated, and transparent. As shown in Fig.1. (1) Longitudinal transmission, achieving the comprehensive collection of government accounting information, step by step reporting, and vertical sharing. Taking the county-level fiscal department as the node, comprehensively collect government accounting information of government departments and units in the region. Ensure the authenticity, reliability and integrity of accounting information through auditing. Provide basis for macroeconomic management and decision-making of relevant government departments through aggregation and analysis. Submit to the higher-level fiscal department to achieve the level-by-level 
collection and vertical sharing of government accounting information. (2) Horizontal sharing, realizing the interconnection and information sharing of government accounting information between the fiscal department, government agencies and legislative bodies. The government accounting information required by government agencies and legislative bodies is uniformly provided by the accounting information platform. It is directly obtained from the accounting information platform through data integration, and the government accounting information in the region is "single out and share resources". It's helpful to establish internal communication, coordination and checks and balances mechanism of the government, to build a multi-governance model under the leadership of the government ${ }^{[9]}$, and to improve the level of government governance. (3) Business integration, promoting the integration of the fiscal sector business system. Government accounting information is the basic information of the fiscal department's various businesses. The relevant systems of the fiscal department directly integrate with the accounting information platform, share government accounting information, and realize the integration of business systems. It's helpful to construct a fiscal operation mechanism of organic connection and mutual restriction of "budget preparation, budget execution, performance evaluation, supervision and inspection" and improve the level of fiscal governance. (4) Open and transparent, meeting the accounting information needs of stakeholders such as the public. Through the establishment of an accounting information platform, the government's accounting information is comprehensively collected, centralized, and unified, providing a smooth channel for the public and other stakeholders to obtain government accounting information. The accounting information platform is used to regularly release relevant information such as government financial reports to the public, provide various services such as information retrieval, provide diversified and personalized services, and better meet the needs of the public and other stakeholders for government accounting information. The construction of the accounting information platform can not only improve the quality of government accounting information disclosure, but also expand the content of information disclosure, thereby improving fiscal transparency.

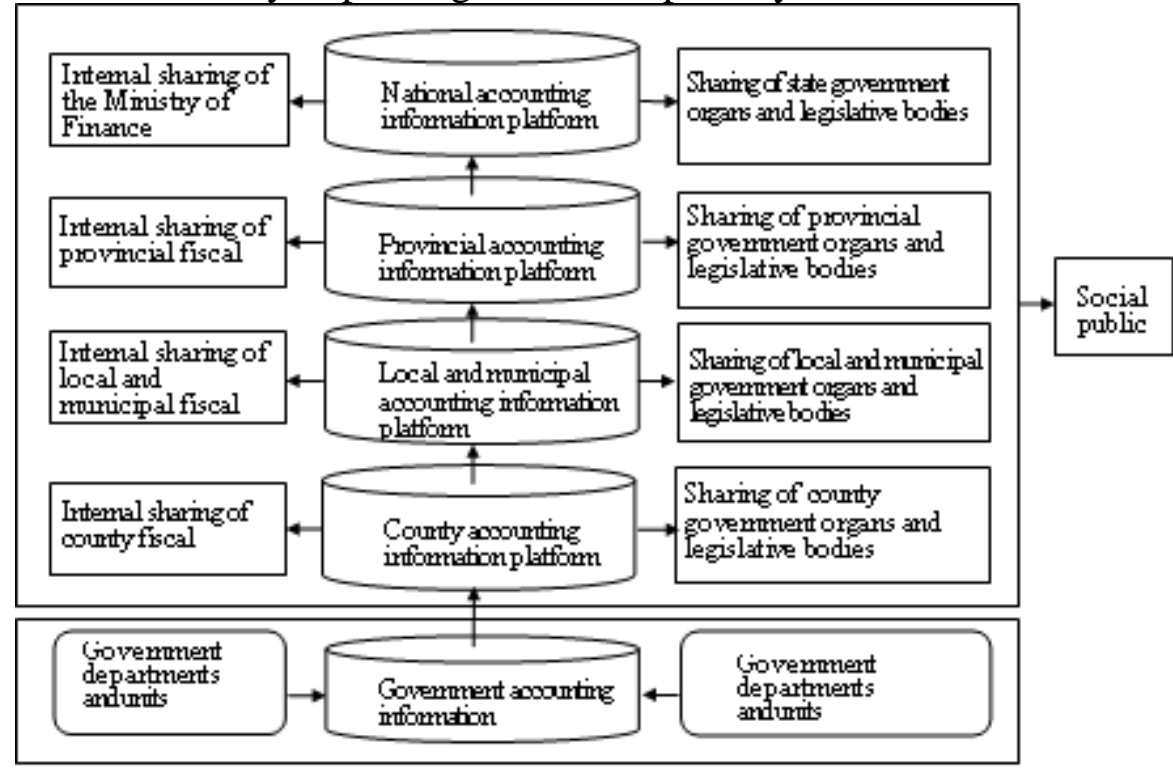

Fig. 1. Mechanism of government accounting information sharing

\subsection{Strategies for the realization of government accounting information sharing}

According to the current management and operation system of government agencies such as the fiscal department, the following suggestions are made for the realization of government accounting information sharing. (1) Establish a general classification standard for government accounting standards, and lay the foundation for government accounting information sharing. Through the establishment of classification standards, the technical specifications of government financial reports are defined to provide uniform standards for the preparation, transmission and use of financial reports, so that information users can obtain, exchange and use accounting information. It can effectively 
reduce the cost of information acquisition and use, and promote public disclosure and information sharing of government accounting information. (2) Promote the integration of business systems and improve the level of fiscal governance. In 2016, the Ministry of Finance proposed the overall goal and thinking of strengthening fiscal information construction ${ }^{[10]}$. Government accounting information is the basic information of the fiscal sector's various businesses. In order to promote the integration of fiscal business systems, government accounting information sharing should be the main content of fiscal information construction. (3) Implement Business Process Reengineering (BPR) to give full play to the effectiveness of government accounting information. The main idea of BPR is to use information technology and modern management methods to maximize the re-integration of business functions and processes, reduce information delivery time, and improve operational efficiency. Government accounting information is important basic information of fiscal management. It penetrates into all aspects of fiscal work, becomes the main business of fiscal management, and transfers, integrates and shares between departments. Therefore, we should restructure and optimize the traditional business processes, re-integrate the functions and division of labor of the original departments, establish the corresponding fiscal governance model, methods and means with fiscal informationization, and improve the level of fiscal management.

\section{Conclusion}

Fiscal transparency is a prerequisite for good government governance, macroeconomic stability and fiscal fairness, and the improvement of fiscal transparency is inseparable from the sharing of government accounting information. In view of the problems existing in the current public disclosure of government accounting information in China, this paper proposes the realization mechanism and path of government accounting information sharing. By establishing an accounting information platform, we can establish an open and transparent sharing service system for government accounting information with vertical transfer, horizontal sharing, and business integration to realize the government's accounting information "single out and share resources". Therefore, information users such as the public can easily obtain accounting information, and the government departments can realize the integration of accounting information and related businesses. It's helpful to improve fiscal transparency, and give full play to the role of government accounting in government governance.

\section{Acknowledgment}

This study is supported by the National Social Science Fund Project "Research on Accounting Information Sharing Mechanism from the Perspective of National Governance", No: 15BGL057.

\section{References}

[1] Weiping $\mathrm{Yu}$, Gather Accounting forces to promote financial transparency and sustainable economic growth - a speech at the 19th world congress of accountants, Chinese Certified Public Accountants, No. 12, pp. 5-7, 2014.

[2] IBP, Open budget survey 2017, International Budget Partnership, 2017.

[3] Peng Xiao, and Yan Li, Research on China's fiscal transparency based on Lüder government accounting environment assessment model, Public Administration Review, Vol.4, No.2, pp. 133-150, 2011.

[4] Youqi Shi, and Zhikun Yang, The rule of law path of Chinese government governance, Chinese Social Science, No.1, pp. 66-89, 2018.

[5] Zhihua Wei, Yaqing Lin, and Zhou Xiong, Research progress on financial transparency, Economic Trends, No.3, pp. 136-149, 2017. 
[6] Xiaoxia Liu, and Jianfa Li, Research on the problem of fiscal transparency in China, Journal of Xiamen University (Philosophy and Social Sciences Edition), No.6, pp. 34-41, 2008.

[7] G. Kopits, and J. D Craig, Transparency in government operations, IMF Occasional Paper, No. $158,1998$.

[8] Qifa Peng, and Jing Wu, Service-oriented government, e-government and government financial information network disclosure, Financial Communication, No.2, pp. 51-54, 2015.

[9] Zhibin Chen, and Jingtao $\mathrm{Li}$, The achievement of good governance and governance effect of government accounting, Accounting Research, No.5, pp. 13-19, 2015.

[10] Kun Liu. Deepen the Understanding of innovative ideas and strive to create a new situation of national fiscal informationization work, China Finance, No.15, pp. 6-8, 2016. 